Studia Oecumenica 17 (2017)

DOI: $10.25167 / \mathrm{SOe} / 17 / 2017 / 269-286$

PiOTR KopIEC

Wydział Teologii KUL

\title{
Chrzest i Eucharystia w dialogach katolicko-luterańskim i katolicko-reformowanym
}

\author{
Baptism and Eucharist \\ in the Catholic-Lutheran and the Catholic-Reformed Dialogues
}

\begin{abstract}
Topography of interconfessional theological relations contains of tens doctrinal dialogues conducted on the world levels and of numerous local dialogues. Due to the number of believers of the represented churches as well as theological importance for other dialogues, a special significance is given to the Catholic-Lutheran and Catholic-Reformed dialogues on the world level. Baptism and Eucharist are the most crucial issues of ecumenical relations and the most important areas of theological conversations. Article aims to present the main achievements of these dialogues regarding baptism and Eucharist and to distinct the main divergences that are still existed between churches in this area. It describes differences between both examples of dialogues. Furthermore, it explains why baptism is declared to be the ecumenical starting point whereas Eucharist is the ecumenical final point.
\end{abstract}

Keywords: ecumenical dialogue, Catholic, Lutheran, Reformed, baptism, Eucharist.

\section{Streszczenie}

Topografię międzykościelnych relacji teologicznych określa kilkadziesiąt dialogów toczonych na forum światowym i przez reprezentantów Kościołów bądź federacji Kościołów, nie zapominając o ogromnej liczbie dialogów toczonych na szczeblu lokalnym bądź krajowym. Wśród nich bardzo istotne miejsce zajmują dialogi katolicko-luterański i katolicko-reformowany, nie tylko ze względu na liczebność Kościołów, które reprezentują, ale również ze względu na znaczenie teologiczne dla innych dialogów. Chrzest i Eucharystia są kluczowymi zagadnieniami poruszanymi w obrębie tych dialogów. Artykuł ma na celu przedstawienie podstawowych osiągnięć omawianych dialogów oraz kontrowersji, które wciąż dzielą Kościoły. Omawia różnice w stopniu ekumenicznej zbieżności między dialogiem katolicko-luterańskim i katolicko-reformowanym. Wykazuje również, dlaczego chrzest traktowany jest jako ekumeniczny punkt wyjścia a Eucharystia jako ekumeniczny punkt dojścia.

Słowa kluczowe: dialog ekumeniczny, katolicki, luterański, reformowany, chrzest, Eucharystia. 
Zainicjowanie dwustronnych dialogów doktrynalnych otwiera jeden z głównych rozdziałów historii ekumenizmu. Ekumenizm, będący dotychczas procesem wewnętrznym chrześcijaństwa protestanckiego, oraz, choć w węższym zakresie, prawosławnego mocno przyśpieszył po Soborze Watykańskim II, który otworzył Kościół katolicki na ekumeniczne relacje międzywyznaniowe. Na fali posoborowego entuzjazmu doszło do prawdziwej ekumenicznej eksplozji, która przejawiała się w wielkiej ilości spotkań, wspólnych modlitw, nawiązujących się międzywyznaniowych relacji przyjaźni, nowo powstających ruchów i organizacji. Dialogi doktrynalne prowadzone z upoważnienia najwyższych władz danych Kościołów stanęły więc na szczycie bardzo różnorodnej i dynamicznie rozwijającej się rzeczywistości. Stały się, w swych obszarach wyznaniowych, teologicznym punktem odniesienia dla całego ruchu ekumenicznego, mając na celu opracowanie wiarygodnych i reprezentatywnych zasad dążenia do wspólnego wyznania wiary i przedstawiając, tam, gdzie jest to możliwe, treści teologicznego uzgodnienia w sprawach do tej pory spornych.

W panującym dzisiaj przekonaniu dialogi doktrynalne nie osiągnęły rezultatów odpowiadających poziomowi pokładanych w nich nadziei. Mówi się raczej o stagnacji bądź apatii w ruchu ekumenicznym, a niedostatek uzgodnień teologicznych podaje się niekiedy jako dowód podważający sens ekumenizmu. Cieniem na dialogach doktrynalnych kładą się również pogłębiające się różnice pomiędzy niektórymi wyznaniami w spojrzeniu na porządek kościelny oraz zagadnienia moralno-etyczne i społeczne. Dobrze ilustruje to spostrzeżenie kard. Kurta Kocha, który w wykładzie pt. Rozwój i wyzwania dzisiejszego ekumenizmu, odnosząc się do aktualnej sytuacji ekumenicznej, sparafrazował znany wszystkim ekumenistom slogan ruchu „Życie i Działanie”: „wiara dzieli, działanie łączy” na „wiara łączy, etyka dzieli”" Nie zmienia to faktu, że usiłowania dialogów doktrynalnych pozostają fundamentem, na którym opiera się proces dążenia do jedności podzielonych chrześcijan.

\section{Historia dialogów katolicko-luterańskiego i katolicko-reformowanego}

Topografię międzykościelnych relacji teologicznych określa kilkadziesiąt dialogów toczonych na forum światowym i przez reprezentantów Kościołów bądź federacji Kościołów, nie zapominając o ogromnej ilości dialogów toczonych na szczeblu lokalnym bądź krajowym. Wśród nich bardzo istotne miejsce zajmują dialogi: katolicko-luterański i katolicko-reformowany, nie tylko ze względu na

${ }^{1} \mathrm{~K}$. Koch, The Development and Challenges of Ecumenism Today, http://www.katolsk.no/tro/ tema/ekumenikk/artikler/developments-and-challenges-in-ecumenism-today (10.06.2016). 
liczebność Kościołów, które reprezentują, ale również ze względu na znaczenie teologiczne dla innych dialogów. Teologia luterańska oraz teologia reformowana są bowiem podstawowymi systemami teologicznymi, z których wywodzą się również inne wyznania protestanckie.

Dialog katolicko-luterański rozpoczął się w 1967 r., poprzedzony utworzeniem grupy roboczej, która miała na celu opracowanie zarówno podstawowych tematów, jak i zasad dialogu. Z inicjatywą podjęcia rozmów wystąpiła w 1964 r. Światowa Federacja Luterańska, utworzona w 1947 r. organizacja zrzeszająca Kościoły luterańskie z całego świata. W konsekwencji więc na poziomie światowym reprezentantem strony luterańskiej jest Światowa Federacja Luterańska, a strony katolickiej - Papieska Rada do spraw Jedności Chrześcijan. Ukoronowaniem rozmów było podpisanie 31 października 1999 r. w Augsburgu Wspólnej deklaracji w sprawie nauki o usprawiedliwieniu (The Joint Declaration on the Doctrine of Justification), dokumentu, który deklarowany był jako kończący kontrowersje odnoszące się do rozumienia zagadnienia usprawiedliwienia jedynie przez wiarę, a więc kluczowego teologicznego twierdzenia luteranizmu. Podpisanie deklaracji do dziś uważane jest za jeden z największych sukcesów ekumenizmu doktrynalnego ${ }^{2}$. Do momentu publikacji dialog miał cztery fazy. Pierwsza obejmowała lata 1967-1972 i zakończona była przyjęciem dokumentu Ewangelia i Kościót, zwanego Raportem z Malty. Głównymi tematami tej fazy były: stanowiący kolejną teologiczną kontrowersję stosunek między Pismem Świętym oraz Tradycją kościelną oraz Kościół i jego rozumienie. Druga faza miała miejsce w latach 1973 1984 i przyniosła owoce w postaci przyjęcia sześciu dokumentów: uzgodnienia na temat Eucharystii, zatytułowanego Wieczerza Pańska (1978); uzgodnienia dotyczącego jedności, pod tytułem Drogi do wspólnoty (1980); uzgodnienia na temat najważniejszego luterańskiego wyznania wiary, a więc Konfesji Augsburskiej, noszącego tytuł Wszyscy pod jednym Chrystusem (1980); dokumentu dotyczącego zagadnienia posługiwania duchowego, pod tytułem Urząd duchowny w Kościele (1981); dokumentu omawiającego stosunek do osoby Marcina Lutra zatytułowanego Marcin Luter - świadek Jezusa Chrystusa (1983); wreszcie, uzgodnienia dotyczącego modelów jedności, pod tytułem Jedność przed nami. Modele, formy $i$ etapy kościelnej wspólnoty luterańsko-katolickiej. Trzecia faza rozpoczęła się w 1986 r. i zakończona została w 1993 r. przyjęciem dokumentu Kościót i usprawiedliwienie (Church and Justification). Odnośnie do tematu usprawiedliwienia najważniejszym, niejako osobnym wydarzeniem było przyjęcie wspomnianej deklaracji o usprawiedliwieniu ${ }^{3}$. Dokument, którego oficjalne podpisanie nastąpiło

\footnotetext{
${ }^{2} \mathrm{Na}$ temat historii podpisania deklaracji oraz jej treści zob. S.C. NAPIÓRKowsKi, Bóg łaskawy, Warszawa 2000.

3 S.C. NAPIÓRKowsKi, Topografia dialogów międzywyznaniowych, w: W. HRYNIEWICZ, J.S. GAJEK, S.J. KozA, Ku chrześcijaństwu jutra. Wprowadzenie do ekumenizmu, Lublin 1996, 528.
} 
pod symboliczną datą 31 października 1999 r., został ostatecznie zredagowany już w 1997 r. W latach 1998 i 1999 opublikowano serię oświadczeń prezentujących stanowiska obu stron oraz różnych organizacji ekumenicznych (m.in. Ekumenicznego Instytutu Johanna-Adama Möhlera w Paderborn).. Doszły do głosu również oświadczenia krytyczne wobec deklaracji, zaprezentowane np. w stanowisku amerykańskiego Kościoła Luterańskiego-Synodu Missouri (Lutheran ChurchMissouri Synod).

Czwarta faza dialogu katolicko-luterańskiego na poziomie światowym obejmowała lata 1995-2005 i zakończyła się przyjęciem dokumentu Apostolskość Kościoła (The Apostolicity of the Church). W zamierzeniu komisji dialogowej temat apostolskości miał być podejmowany wraz z zagadnieniami moralno-etycznymi oraz dotyczącymi Eucharystii. Okazał się jednak na tyle obszerny, że ostatecznie ta faza dialogu na nim właśnie się skoncentrowała. Faza piąta rozpoczęła się w 2009 r. i trwa dotychczas, a jej owocem jest przyjęty już w 2013 r. dokument Od konfliktu do komunii (From Conflict to Communion) ${ }^{4}$, który przygotowywał Kościoły na obchody pięćsetlecia Reformacji i akcentował konieczność wykorzystania tej daty dla wspólnej reinterpretacji historii i wykorzystania jej w procesie zbliżenia. Autorzy dokumentu podkreślają, że rok upamiętnienia Reformacji uzmysławia nam dwa wyzwania: „oczyszczenie i uzdrowienie pamięci oraz odnowienie jedności chrześcijańskiej w zgodzie z prawdą ewangelii Jezusa Chrystusa (Ef 4,4-6)"s.

Dialog katolicko-reformowany zainicjowano w 1968 r. po decyzji Sekretariatu do spraw Jedności Chrześcijan oraz Aliansu Kościołów Reformowanych. Powołana w 1969 r. komisja studiów określiła jego kluczowe tematy. Jako rezultat rozmów w latach 1970-1977 opublikowano dokument zatytułowany Obecność Chrystusa w Kościele $i$ w świecie (The Presence of Christ in Church and World). W 1984 r. zainicjowano kolejną fazę dialogu odnośnie do tematu: „Kościół jako lud Boży, ciało Chrystusa i świątynia Ducha Świętego" ". Zakończyła się ona w 1990 r. podpisaniem wspólnego dokumentu zatytułowanego Ku wspólnemu rozumieniu Kościoła (Towards a Common Understanding of the Church). Trzecia faza obejmowała lata 1998-2004 i naznaczona była kontrowersjami spowodowanymi zwłaszcza opublikowaniem encykliki Dominus Iesus. W 2007 r. podpisano dokument będący owocem kolejnego etapu dialogu, zatytułowany „Kościół jako wspólnota wspólnego świadectwa Królestwa Bożego" (The Church as Community of Common Witness to the Kingdom of God). Uzgodnienie to nawiązywało do

\footnotetext{
${ }^{4}$ From Conflict to Communion. Lutheran-Catholic Common Commemoration of the Reformation in 2017, Leipzig 2013.

5 Tamże, 7.

${ }^{6}$ S.C. NAPIÓRKOWSKI, Topografia dialogów międzywyznaniowych, 530.
} 
ustaleń z 1990 r. zawartych w Ku wspólnemu rozumieniu Kościoła i precyzowało podniesioną tam komplementarność eklezjologicznych zdefiniowań Kościoła jako creatura verbi, charakterystycznego dla teologii reformowanej, oraz jako sacramentum gratiae, wywodzącego się z teologii katolickiej. Należy dodać, że $\mathrm{w}$ trakcie dialogu strona reformowana podlegała strukturalnym przekształceniom. W 1970 r., wobec połączenia Aliansu Kościołów Reformowanych (Alliance of the Reformed Churches) i Międzynarodowej Rady Kongregacjonalistycznej (International Congregational Council), powstał Światowy Alians Kościołów Reformowanych (World Alliance of Reformed Churches). Natomiast w 2010 r., poprzez zjednoczenie Światowego Aliansu Kościołów Reformowanych oraz Reformowanej Rady Ekumenicznej, doszło do utworzenia Światowej Wspólnoty Kościołów Reformowanych (World Communion of Reformed Churches).

Warto wspomnieć również o trójstronnym dialogu katolicko-reformowano-luterańskim. Miał on miejsce w latach 1971-1976 i dotyczył głównie tematów związanych z problemem małżeństw mieszanych i teologią małżeństwa. Jego owocem jest uzgodnienie zatytułowane Teologia małzeństwa $i$ problem matżeństw mieszanych (The Theology of Marriage and the Problem of Mixed Marriages).

Wreszcie, bardzo istotnym punktem odniesienia dla dialogu ekumenicznego na temat chrztu, Eucharystii i posługiwania duchownego jest wypracowany w 1979 r. na łonie komisji „Wiara i Ustrój” Światowej Rady Kościołów dokument Chrzest, Eucharystia i postugiwanie duchowne (Baptism, Eucharist, Ministry), tzw. Dokument z Limy. Został on podpisany również przez katolickich członków tej komisji, a choć w wyniku różnych tendencji w dialogu ekumenicznym jego recepcja napotkała na bardzo poważne przeszkody, to jednak jest on wciąż wskazywany jako jeden z największych ekumenicznych sukcesów dotychczas osiągniętych ${ }^{7}$.

\section{Sakrament chrztu jako punkt wyjścia dialogu ekumenicznego}

Wzajemne uznanie chrztu przez Kościoły chrześcijańskie jest ekumeniczną bramą wejściową do dialogu i pierwszym warunkiem rozpoznania tożsamości chrześcijańskiej wiernych danego Kościoła. Kościół katolicki taką pierwotną funkcję chrztu w ekumenicznym kontekście relacji z Kościołami poreformacyjnymi wyraził w 22. punkcie Dekretu o ekumenizmie Unitatis redintegratio: „Po-

\footnotetext{
${ }^{7}$ Na temat podsumowania dialogu Kościoła katolickiego z Kościołami poreformacyjnymi zob. P. KANTYKa, Dialog ekumeniczny katolicko-protestancki-założenia, zakres, rezultaty, w: M. SKŁADANOWSKI, T. SYcZEWSKI (red.), Ekumenizm w posoborowym półwieczu. Sukcesy i trudności katolickiego zaangażowania na rzecz jedności chrześcijan, Lublin 2013, 29-50.
} 
przez sakrament chrztu, ilekroć jest należycie udzielany zgodnie ustanowieniem Pańskim i przyjmowany z odpowiednim nastawieniem duszy, człowiek zostaje prawdziwie wcielony w Chrystusa ukrzyżowanego i uwielbionego oraz odradza się do uczestnictwa w życiu Bożym, zgodnie ze słowami Apostoła: «Razem z Nim pogrzebani w chrzcie, w którym też razem zostaliście wskrzeszeni przez wiarę w moc Boga, który go wskrzesił» (Kol 2,12). Chrzest zatem stanowi sakramentalny węzeł jedności między wszystkimi, którzy zostali przez niego odrodzeni. Jednakże sam chrzest jest jedynie zaczątkiem, jako że całą swoją istotą zmierza do osiągnięcia pełnego życia w Chrystusie. Chrzest więc prowadzi do pełnego wyznania wiary, do pełnego wcielenia w zgodny z wolą Chrystusa plan zbawienia, do pełnego wreszcie włączenia we wspólnotę eucharystyczną. Chociaż odłączonym od nas Wspólnotom kościelnym brakuje wypływającej ze chrztu pełnej jedności z nami, i choć w naszym przekonaniu nie zachowały one autentycznej i całej istoty eucharystycznego Misterium, głównie przez brak sakramentu kapłaństwa, to jednak sprawując w świętej Uczcie pamiątkę śmierci i zmartwychwstania Pańskiego, wyznają, że oznacza ona życie w łączności z Chrystusem i oczekują Jego chwalebnego przyjścia. Dlatego przedmiotem dialogu powinna być nauka o Uczcie Pańskiej, o innych sakramentach oraz o kulcie i o posługach Kościoła".

Wspomniany Dokument z Limy wyliczył również podobieństwa w teologii chrztu. Ich katalog tworzą zbieżności: „Trynitarne i chrystocentryczne ujęcie istoty chrztu; podkreślenie, że chrzest jest z woli Boga, nie z ustanowienia ludzkiego, i że jako sakrament Kościoła chrzest rzeczywiście pochodzi od Jezusa Chrystusa; stwierdzenie, że chrzest jest sakramentem (chociaż pozostają wątpliwości, co oznacza termin «sakrament»); uznanie, że chrzest jest znakiem wymagającym określonych elementów rytualnych, jest czynnością kościelną i wyraża wiarę Kościoła; nauka o tym, że chrzest oznacza udział w śmierci Chrystusa, a zarazem jest darem Ducha Świętego; stwierdzenie, że chrzest jest darem Bożym, jak i ludzką odpowiedzią na ten dar; potwierdzenie tradycyjnej nauki chrześcijańskiej o tym, że chrzest jest aktem niepowtarzalnym oraz wskazanie klasycznych elementów celebracji chrztu, które umożliwią wspólne uznanie chrztu przez Kościoły i wspólnoty"s.

Oba dokumenty stały się podstawą podejmowania międzywyznaniowych rozmów na temat teologii chrztu. W konsekwencji, w różnych dialogach lokalnych, nie tylko między katolikami i luteranami, ale i między wszystkimi Kościołami chrześcijańskimi danego państwa czy terytorium, sakrament chrztu jest przedmiotem wzajemnych uzgodnień i uznań. Warto wspomnieć tu przykład amery-

${ }^{8}$ M. SkŁadanowski, Problemy recepcji Dokumentu z Limy z perspektywy katolickiej, „Roczniki Teologii Ekumenicznej" 4 (2012), 147n. 
kański, gdzie katolicy i luteranie w dokumencie Jeden chrzest na odpuszczenie grzechów (One Baptism for a Remission of Sins) z 1966 r. uznali, że „jesteśmy w uzasadniony sposób pewni, że nauczanie poszczególnych naszych tradycji odnośnie do chrztu zawiera się w substancjalnym uzgodnieniu"9; przykład polski, gdzie w 2000 r. uzgodniono wzajemne uznanie chrztu przez Kościół rzymskokatolicki w Polsce oraz Kościoły zrzeszone w Polskiej Radzie Ekumenicznej; przykład niemiecki, gdzie podobne uznanie zostało podpisane pomiędzy Kościołem rzymskokatolickim w Niemczech a Kościołami zrzeszonymi we Wspólnocie Roboczej Kościołów Chrześcijańskich (Arbeitsgemeinschaft der Christlichen Kirchen) w 2007 r. w Magdeburgu; czy przykład holenderski, gdzie w 2012 r. dokonano oficjalnego wzajemnego uznania chrztu przez Kościoły skupione w Holenderskiej Radzie Kościołów oraz Kościół rzymskokatolicki.

\subsection{Dialog katolicko-luterański}

W dialogu katolicko-luterańskim chrzest nie jest traktowany jako czynnik kontrowersji, podkreśla się raczej jego rolę inicjującą życie chrześcijańskie i jego sakramentalny charakter oraz zachęca się do podejmowania aktów wzajemnego uznania chrztu jako czynnika ekumenicznego. Tak jest np. w Raporcie z Malty, gdzie w rozważaniu teologii urzędu duchownego wspomina się o rozumieniu sakramentów w poszczególnych wyznaniach, a zwłaszcza w rozpatrywaniu szans na interkomunię ${ }^{10}$. Chrzest ujmuje się właśnie jako punkt wyjścia dla uzgodnień na temat Eucharystii: „Istnieje zgoda, że nasz wspólny chrzest jest ważnym punktem wyjścia w sprawie wspólnoty eucharystycznej" ${ }^{11}$. W dokumencie Drogi do wspólnoty oba Kościoły podkreślają soteriologiczny charakter sakramentów, również chrztu, uznają konieczność pielęgnacji rytuału chrzcielnego oraz uświadamiania wiernych, co chrzest oznacza w życiu chrześcijani$\mathrm{na}^{12}$. W uzgodnieniu Urząd duchowny w Kościele podkreślone zostaje znaczenie chrztu dla nauki o kapłaństwie powszechnym chrześcijan: „Przez chrzest wszyscy członkowie wspólnie tworzą jeden kapłański lud Boży”"13. W tekście Kościót $i$ usprawiedliwienie zaakcentowana zostaje wspólnototwórcza i eklezjotwór-

9 J. Burgess, J. Gross (red.), Building Unity: Ecumenical Dialogues with Roman Catholic Participation in Unites States (Ecumenical Documents IV), New York 1989, 90.

${ }^{10}$ Raport luterańsko-rzymskokatolickiej komisji studiów „Ewangelia a Kościót” (1972) (Raport z Malty), w: K. KARSKI, S.C. NAPIÓRKOWSKI (red.), Bliżej wspólnoty. Katolicy i luteranie w dialogu 1965-2000, Lublin 2003, 39-67 (nr 59).

${ }^{11}$ Tamże, $\mathrm{nr} 70$.

12 Ways to Community, w: H. Meyer, L. Visher (red.), Growth in Agreement I: Reports and Agreed Statements of Ecumenical Conversations on a World Level, 1972-1982, Geneva 2007, 190-214 (nr 67).

13 The Ministry in the Church, w: Growth in Agreement I, 248-275 (nr 18). 
cza rola chrztu ${ }^{14}$. Wreszcie, w uzgodnieniu Apostolskość Kościoła przypomina się z jednej strony słowa Lutra, że w Kościele rzymskim istnieją: „prawdziwe Pismo Święte, prawdziwy chrzest, prawdziwy sakrament, prawdziwe klucze przebaczenia grzechów, prawdziwy urząd głoszenia i prawdziwy Katechizm"15, z drugiej zaś stwierdzenia z punktów 8. i 15. Konstytucji dogmatycznej o Kościele Lumen gentium, że również poza organizmem Kościoła katolickiego „znajdują się liczne pierwiastki uświęcenia i prawdy, które jako właściwe dary Kościoła Chrystusowego nakłaniają do jedności katolickiej”, i że są tacy, „którzy naznaczeni są chrztem, dzięki któremu łączą się z Chrystusem, a także uznają i przyjmują inne sakramenty w swoich własnych Kościołach czy wspólnotach kościelnych"16.

\subsection{Dialog katolicko-reformowany}

W dialogu katolicko-reformowanym na poziomie światowym chrzest również nie jest przedstawiany jako zagadnienie kontrowersyjne, przeciwnie, ujmowany jest jako fundament działań ekumenicznych i czynnik łączący podzielonych chrześcijan. W dokumencie Obecność Chrystusa w Kościele i świecie wskazuje się na znaczenie lokalnych dialogów zmierzających do wzajemnego uznania chrztu. Podkreśla się również eklezjotwórczą rolę chrztu ${ }^{17}$. Zdecydowanie więcej o sakramencie inicjacji chrześcijańskiej pisze dokument Ku wspólnemu rozumieniu Kościoła. Już we wstępie do tego uzgodnienia stwierdza się, że oba Kościoły są połączone różnorakimi więzami, wśród których są: uznanie Jezusa Chrystusa za Pana i Zbawiciela, trynitarna wiara Kościoła apostolskiego przez stulecia oraz jeden chrzest ${ }^{18}$. W dalszym toku treści dokument przypomina ekumeniczne znaczenie chrztu, podkreślone w 22. punkcie Unitatis redintegratio, i akcentuje, że jest on jednym z kluczowych aktów prowadzących na drogę pojednania: ,(...) przez chrzest $\mathrm{i}$ inne czynniki eklezjalne pomimo ciągłych podziałów między chrześcijanami reformowanymi i katolikami istnieje rzeczywista, choć niedoskonała wspólnota"19. Omawia podobieństwa w przyjmowaniu pneumatologicznej i eklezjologicznej perspektywy chrztu oraz zachęca do podejmowania działań prowadzących do wzajemnego

${ }^{14}$ Church and Justification, w: J. Gros, H. Meyer, W. Rusch (red.), Growth in Agreement II: Reports and Agreed Statements of Ecumenical Conversations on a World Level 1982-1998, Geneva - Grand Rapids 2000, 438-442.

${ }^{15}$ The Apostolicity of the Church. Study Document of the Lutheran-Roman Catholic Commission on Unity, Minneapolis 2006, 26n (nr 99).

16 Tamże, nr 119.

17 The Presence of Christ in Church and World, w: Growth in Agreement I, 434-463 (nr 79). (nr 4).

${ }_{18}$ Towards a Common Understanding of the Church, w: Growth in Agreement II, 780-818

19 Tamże. 
uznania chrztu przez Kościoły na poziomie lokalnym. Wreszcie, w dokumencie Kościót jako komunia wspólnego świadectwa Królestwa Bożego obie strony przyznają, że chrzest jest punktem łączącym chrześcijan pomimo wielu różnic w rozumieniu wiary i sprawia, że „należą oni do siebie”20. Powtarzają również wielokrotnie już stwierdzaną ekumeniczną funkcję chrztu: „Dialog, uzdrowienie pamięci, wysiłki wspólnego świadectwa - wszystko to jest dla nas ciągłym wyzwaniem pogłębiania rozwijających się relacji między nami, relacji, które ugruntowane są w jednym chrzcie w Chrystusie"21.

\section{Sakrament Eucharystii jako ekumeniczny punkt dojścia}

O ile chrzest jest punktem wyjścia w relacjach ekumenicznym, o tyle wspólna Eucharystia jest traktowana jako punkt dojścia. Rozmowy na jej temat należą zaś, obok tematu posługiwania duchownego, do najtrudniejszych kwestii teologicznych, jakie poruszane są w dialogu. Wywołują również najwięcej kontrowersji. Brak możliwości wspólnej celebracji Eucharystii, np. podczas spotkań ekumenicznych, oraz bardzo mocne ograniczenia w możliwości przyjmowania Komunii św. boleśnie przypominają o dalekiej wciąż drodze czekającej Kościoły chrześcijańskie.

Należy wspomnieć, że o ile Kościoły luterańskie i reformowane nie różnią się swym nauczaniem na temat chrztu, o tyle Eucharystia, a zwłaszcza rozumienie obecności Chrystusa są od samego początku głównym teologicznym czynnikiem kontrowersji wewnątrz obu wyznań protestanckich ${ }^{22}$. Nawet podpisanie Konkordii Leuenberskiej, uzgodnienia ustanawiającego wspólnotę ołtarza i urzędu pomiędzy Kościołami luterańskimi, reformowanymi, unijnymi, husyckimi i waldensów, nie doprowadziło do wspólnego nauczania dotyczącego tego centralnego dla teologii nauczania.

Lokując dialogi: katolicko-luterański i katolicko-refomorwany w szerszym kontekście, warto zauważyć, że wspomniany Dokument z Limy wymienia zbieżności pomiędzy teologią katolicką a teologiami Kościołów poreformacyjnych. Szczególnie istotne jest tu pokreślenie, że „źródłami doktryny i praktyki eucharystycznej są Pismo Święte i Tradycja, przy czym uwzględniono starożytne liturgie i teologię ojców Kościoła; stwierdzenie, że Eucharystia została ustanowiona przez Jezusa Chrystusa; silne i stałe powiązanie Eucharystii z ofiarą krzyżową

${ }^{20}$ The Church as Community of Common Witness to the Kingdom of God, "Reformed World" 56 (2007) 2-3, 105-207 (nr 223).

${ }^{21}$ Tamże, nr 234.

${ }^{22}$ K. KARSKI, Osiagnięcia dialogu luterańsko-reformowanego, w: J. BudniaK, P. JASKÓŁA, R. Porada (red.), W nurcie myśli Jana Kalwina, Opole 2009, 53. 
Pana Jezusa i z obecnością Zmartwychwstałego w Kościele, z czego wynika, że Eucharystia nie jest jedynie zebraniem wiernych, lecz należy do centrum wiary chrześcijańskiej; nawiązanie w opisie elementów liturgii do tradycji chrześcijańskiej; objaśnienie treści aktu Kościoła w Eucharystii jako dziękczynienia Ojcu, pamiątki ofiary krzyżowej, wstawiennictwa za światem, epiklezy - wezwania Ducha Świętego oraz uświęcenia wspólnoty; zaakcentowanie eschatologicznego wymiaru Eucharystii będącej zapowiedzią uczty królestwa, jak również podkreślenie, że Eucharystia jest głównym aktem liturgicznym Kościoła - z czym wiąże się zalecenie jej częstego sprawowania"23. Jednak, jak zauważa M. Składanowski, istniejące różnice doktrynalne nie pozwalają na ustanowienie interkomunii bez dalszego dialogu teologicznego ${ }^{24}$.

Ze względu na znaczenie, temat Eucharystii bardzo często poruszany był w dialogach: katolicko-luterańskim i katolicko-reformowanym i nie jest możliwym przeanalizowanie w krótkim opracowaniu poszczególnych jego punktów. Warto natomiast prześledzić pewne reprezentatywne dokumenty, które ukazują rozwój tych rozmów oraz podstawowe treści w nich poruszane.

\subsection{Dialog katolicko-luterański}

W dialogu katolicko-luterańskiego opublikowano zdecydowanie więcej dokumentów odnoszących się w jakimś stopniu do Eucharystii niż w dialogu katolicko-reformowanym. Wynika to przede wszystkim ze zbieżności w centralnym zagadnieniu dotyczącym nauki o Eucharystii, a więc pojmowaniu realnej obecności Chrystusa. Ponieważ, jak już wspomniano, nie jest możliwym prześledzenie w krótkim artykule zapisu historii dialogu dotyczącego tego zagadnienia, warto odnieść się do ostatniego dokumentu, a więc uzgodnienia Od konfliktu do komunii. Jest to tym bardziej zasadne, że zawiera on najnowszy stan dialogu między oboma Kościołami oraz powtarza główne treści dokumentu Wieczerza Pańska, ściśle dotyczącego Eucharystii.

W uzgodnieniu tematowi Eucharystii poświęcony jest cały podrozdział. Zawiera on trzy główne komponenty: przedstawienie luterańskiej nauki na temat Eucharystii, następnie nauczania katolickiego, wreszcie naświetlenie stanu dialogu ekumenicznego na ten temat, wraz z wyliczeniem kontrowersji, które wciąż stanowią przedmiot dyskusji. W uzgodnieniu można wyróżnić jednocześnie dwa wielkie obszary implikujące zarówno zbieżności, jak i kontrowersje, mianowicie, zagadnieniu rzeczywistej obecności Chrystusa podczas Eucharystii oraz rozumienie Mszy św. jako ofiary.

\footnotetext{
${ }^{23}$ M. Sktadanowski, Problemy recepcji Dokumentu z Limy, 148.

${ }^{24}$ Tamże, 149.
} 
W pierwszej i drugiej odsłonie dokument odnosi się do głównych punktów nauczania luterańskiego i zestawia je z nauczaniem katolickim. Przypomina przede wszystkim fakt, że Luter, w odróżnieniu od reformatorów helweckich, przyjmuje realną obecność Chrystusa podczas Eucharystii. Autorzy uzgodnienia nawiązują tu do Debaty Marburskiej z 1529 r., podczas której doszło między Lutrem a Zwinglim do ujawnienia różnic w tym obszarze (Zwingli, jeszcze bardziej radykalnie niż Kalwin, przyjmuje jedynie obecność symboliczną) i do ustalenia tym samym granicy między Reformacją luterańską i helwecką, niezniesionej właściwie aż do dzisiaj. Reformator stwierdza, że w trakcie Wieczerzy Pańskiej obecny jest i daje siebie Chrystus i to niezależnie od wiary przyjmującego ${ }^{25}$. W najkrótszej formie Luter podsumowuje to w Matym Katechizmie: „Co to jest sakrament Ołtarza? (...) Jest to prawdziwe ciało i prawdziwa krew Pana naszego Jezusa Chrystusa, pod chlebem i winem nam chrześcijanom do spożywania i picia przez samego Chrystusa ustanowione" ${ }^{26}$. Różnica pomiędzy ujęciem katolickim i luterańskim polegała na innym rozumieniu sposobu tej obecności. Reformator nie przyjmuje dogmatu o transsubstancjacji, która, jak pisze dokument, dla katolików jest „najlepszą gwarancją utrzymania rozumienia rzeczywistej obecności Jezusa Chrystusa w postaci chleba i wina oraz pewności, że pełna rzeczywistość Jezusa Chrystusa jest obecna w każdej z tych postaci" ${ }^{27}$. Zamiast tego Luter mówi raczej o jednoczesnej obecności ciała i krwi Chrystusa oraz chleba i wina, co można opisać terminem „konsubstancjacja”. Chleb i wino łączą się z ciałem i krwią na zasadzie zjednoczenia sakramentalnego, analogicznie do zjednoczenia natury boskiej i natury ludzkiej w osobie Chrystusa (p. 143). Dokument wspomina również o słynnym porównaniu Lutra, wygłoszonym w Marburgu, że to zjednoczenie sakramentalne podobne jest do połączenia ognia i żelaza w rozżarzonym kawałku żelaza. Współistnienie oznacza, że ciało i krew Chrystusa są rzeczywiście obecne podczas Eucharystii, zaś chleb i wino nie zmieniają swej substancji. W ten sposób sakrament jest rzeczywiście nośnikiem Bożej łaski.

Ciało i krew są obecne $\mathrm{w}$ przestrzeni chleba i wina dzięki przymiotowi wszechobecności Chrystusa (ubiquitas). Wszechobecności tej nie należy rozumieć jednak totalnie, jakby w każdym chlebie i w każdym winie było ciało i krew Chrystusa, ale jako obecność szczególną, charakterystyczną tylko dla Eucharystii i przeznaczoną dla człowieka. Warto przypomnieć, że Luter ostatecznie przery-

${ }^{25}$ From Conflict to Communion, nr 141.

${ }^{26}$ M. Luter, Mały Katechizm, w: Księgi Wyznaniowe Kościoła Luterańskiego, Bielsko-Biała 1999, 51

27 From Conflict to Communion, nr 149. 
wał spory na ten temat postulatem, że obecność Chrystusa w Eucharystii powinna pozostać kwestią wiary ${ }^{28}$.

Jako o pochodnej tego tematu pisze dokument o spornym zagadnieniu przyjmowania Komunii św. pod dwiema postaciami. Dla Lutra praktyka w Kościele katolickim dopuszczająca świeckich jedynie do przyjmowania Ciała Chrystusa była nie do przyjęcia. Strona katolicka przypomniała, że praktyka ta była podyktowana głównie względami praktycznymi.

Pochodną tematu realnej obecności jest kolejny, wspomniany w dokumencie, element nauczania luterańskiego, mianowicie wspólnotowe rozumienie wydarzenia eucharystycznego. Dla Lutra każda celebracja Wieczerzy Pańskiej musi dokonywać się we wspólnocie eklezjalnej, dla której ma ona kluczowe znaczenie soteriologiczne. Wieczerza Pańska jest bowiem sakramentem, w którym Chrystus w rzeczywisty sposób jest obecny we wspólnocie Kościoła, dzięki Niemu utrzymującej się i rozwijającej. We wspólnocie Eucharystii chrześcijanin może więc spotkać Chrystusa i dotknąć obietnicy odpuszczenia grzechów ${ }^{29}$. Stąd też wynikają dwie kontrowersje, o których wspomina dokument: zanegowanie sensu celebracji Mszy prywatnych przez Lutra oraz porzucenie praktyki przechowywania przemienionych ciała i krwi Chrystusa po odprawieniu Mszy św. ${ }^{30} \mathrm{~W}$ tym drugim zagadnieniu dokument przypomina katolickie stanowisko, że usankcjonowana przez Sobór Trydencki praktyka adoracji Najświętszego Sakramentu wynika z faktu, że głównym celem ustanowienia tego sakramentu była Komunia wiernych; Eucharystia jest duchowym pokarmem ${ }^{31}$.

Za główny czynnik kontrowersji uzgodnienie uznaje temat rozumienia Mszy św. jako ofiary. Dla Lutra jest to teza, która radykalnie sprzeciwia się centralnej dla niego nauce o usprawiedliwieniu jedynie przez wiarę oraz chrystocentrycznej zasadzie solus Christus. Myśl, że człowiek może składać ofiarę, pomniejszałaby bowiem wartość ofiary Chrystusa, dokonanej raz-na-zawsze, a także sugerowałaby, że uczestnictwo w Eucharystii jest jakiegoś rodzaju dobrym uczynkiem. W konsekwencji, ,zamiast otrzymać najcenniejszy dar, jakim jest sam, ofiarujący się nam Chrystus, próbowalibyśmy ofiarować coś Bogu, zamieniając w ten sposób Boży dar w dobry uczynek"32. Dokument wspomina jednak jednocześnie o pewnym „ofiarniczym” elemencie w luterskim nauczaniu na

28 S.C. NAPIÓRKowski, Wierzę w jeden Kościót, Tarnów 2003, 261. Odnośnie do nauczania Lutra na temat Eucharystii zob. również: L. GRANE, Wyznanie Augsburskie. Wprowadzenie w podstawowe myśli Reformacji luterańskiej, Bielsko-Biała 2002.

${ }^{29}$ P. KoPIEc, Konsumpcjonizm. Perspektywa protestanckiej wizji człowieka i społeczeństwa, Lublin 2016, 252.

${ }^{30}$ From Conflict to Communion, nr 144-146.

${ }^{31}$ Tamże, nr 150.

32 Tamże, nr 147. 
temat Wieczerzy Pańskiej, wynikającym z antropologii chrześcijanina. Usprawiedliwiony człowiek ma mianowicie potrzebę wyrażania dziękczynienia i wyrażenia, że jego kondycja została radykalnie zmieniona dzięki przyjęciu daru, jakim jest ofiarujący się w Eucharystii Chrystus. W ten sposób dialog stara się dojść do wspólnego rozumienia, zachowując jednocześnie podstawowe prawdy antropologii luterańskiej, zawarte np. w piśmie $O$ wolności chrześcijanina czy też $O$ dobrych uczynkach.

W perspektywie katolickiej, jak pisze dokument, nie mogło być mowy o rezygnacji z przyjmowania ofiarniczego charakteru Eucharystii. Potencjał konwergencji pojawił się wraz z liturgiczną odmową Soboru Watykańskiego II i ponownej koncentracji na koncepcji ,anamnezy” (anamnesis). Choć kwestia rozumienia Mszy św. jako ofiary wciąż pozostaje ekumeniczną kontrowersją ${ }^{33}$, to jednak, jak stanowczo stwierdza dokument, pojęcie anamnesis ,prowadziło do lepszego rozumienia, jak sakrament Eucharystii jako upamiętnienie czyni skutecznymi wydarzenia zbawcze i, w szczególności, ofiarę Chrystusa"34.

Trzecia część dokumentu jest podsumowaniem zagadnień poruszonych w pierwszej i drugiej wraz ze skatalogowaniem różnic i zbieżności. I tak, uzgodnienie jednoznacznie i stanowczo stwierdza, że kwestia rzeczywistej obecności Chrystusa podczas Eucharystii nie stanowi kontrowersji między oboma wyznaniami. Przypomina stwierdzenie z dokumentu Wieczerza Pańska, że „w sakramencie Wieczerzy Pańskiej Jezus Chrystus, prawdziwy Bóg i prawdziwy człowiek jest obecny w pełni i całkowicie, w Jego ciele i krwi, pod postaciami chleba i wina" 35 . Dodatkowo akcentuje, że wraz z dialogiem luteranie przyznają, że ciało i krew Chrystusa nie pozostają po prostu chlebem i winem, ale że dostępują pewnej „przemiany”. Co do kontrowersji wynikających z rozumienia trwania Wieczerzy Pańskiej, katolicy przyznają, że praktyka czczenia Najświętszego Sakramentu nie sprzeciwia się rozumieniu Eucharystii jako duchowego posiłku, zaś luteranie deklarują traktowanie komunikantów po zakończeniu Eucharystii z szacunkiem ${ }^{36}$.

Odnośnie do drugiego wielkiego obszaru dialogowego dotyczącego kwestii Eucharystii, a więc zagadnienia jej ofiarniczego charakteru, uzgodnienie po raz kolejny przypomniało ustalenia z dokumentu Wieczerza Pańska mówiące, że kluczową rolę w rozwiązywaniu kontrowersji odegrało pojęcie anamnesis. Pomogło odnaleźć właściwą relację między rozumieniem ofiary Chrystusa jako jednej na zawsze a Wieczerzą Pańską. Dzieło zbawcze, które upamiętnia Eucharystia, staje

${ }_{33}$ F. Schulz, Die Eucharistiefeier im katholischen Weltkatechismus. Katholische lex credendi und evangelische lex orandi. Konvergenz und Divergenz, LJb 44 (1994), 13n.

${ }^{34}$ From Conflict to Communion, nr 146.

${ }^{35}$ Tamże, nr 154.

36 Tamże, nr 156. 
się obecne dzięki mocy Ducha Świętego, a wspólnota eucharystyczna łączy się z tymi, którzy już doświadczali zbawczych dzieł w przeszłości. Stąd też decydująca jest tutaj sakramentalność Eucharystii. W niej bowiem Chrystus, rzeczywiście obecny, obecny jest wraz z wszystkimi swymi dziełami zbawczymi, ze swym zastępczym działaniem, a więc życiem, cierpieniem, śmiercią i zmartwychwstaniem. Dokument konkluduje, że jedna na zawsze ofiara Chrystusa dostępna jest w „,sakramentalnej modalności”; „nie tylko skutki wydarzeń na krzyżu, ale sam krzyż obecny jest podczas Wieczerzy Pańskiej, bez konieczności powtarzania albo uzupełniania dzieł zbawczych"37. Takie rozumienie Eucharystii jako upamiętnienia pozwala - zdaniem dokumentu - na stwierdzenie, że różnice pomiędzy katolikami i luteranami są akceptowalne (tolerable).

Wreszcie, dokument nadmienia dwa zagadnienia o różnym znaczeniu dla dialogu. Pierwsze zawiera konkluzję poruszanego już wcześniej tematu kontrowersji związanych z przyjmowaniem Komunii pod dwiema postaciami. Przypominając stwierdzenie z dokumentu Wieczerza Pańska, stwierdza, że dla obu stron dialogu „chleb i wino należą do kompletnej formy Eucharystii" ${ }^{38}$. Drugie zagadnienie, dotyczące przewodniczenia celebracji Eucharystii, otwiera obszar jednej z największych dzisiejszych kontrowersji teologicznych, jaką jest rozumienie posługiwania duchownego. Tu dokument przytacza jedynie ustalenie z Wieczerzy Pańskiej, że katolicy i luteranie przyznają, iż „celebracja Eucharystii zakłada przewodniczenie szafarza wyznaczonego przez Kościół"39. Rozumienie tego urzędu jest jednak różne.

Uzgodnienia dotyczące chrztu i Eucharystii w dialogu katolicko-luterańskim dostarczają więc wielu ekumenicznych nadziei. Zwłaszcza w tym drugim obszarze, niosącym dotychczas wiele kontrowersji sięgających centralnych punktów obu systemów teologicznych - tu należy wspomnieć zwłaszcza o rozumieniu Eucharystii jako ofiary - dialog doprowadził do znacznego zbliżenia. Rozbieżności natomiast pozostają $\mathrm{w}$ rozumieniu urzędu duchownego, a wręcz powiększają się wraz z przyjmowaniem przez Kościoły luterańskie ordynacji kobiet.

\subsection{Dialog katolicko-reformowany}

Jak już wspomniano, dialog katolicko-reformowany już u samych podstaw systemów teologicznych napotyka na duże większe trudności. Teologia reformowana, na której piętno odcisnęło kilku teologów, ale przede wszystkim Kalwin i Zwingli, odrzuciła bowiem nauczanie o rzeczywistej obecności Chrystusa

\footnotetext{
37 From Conflict to Communion, nr 159.

38 Tamże, nr 160.

39 Tamże, nr 161.
} 
podczas Eucharystii ${ }^{40}$. Dla Kalwina obecność ta miała charakter duchowy, dla Zwingliego - symboliczny. Dlatego też samych uzgodnień dialogu na poziomie światowym dotyczących Eucharystii jest mniej i nie sięgają one tak głęboko, jak w przypadku dialogu katolicko-luterańskiego.

Najobszerniej odniósł się do zagadnienia Eucharystii pierwszy dokument dialogu, a więc Obecność Chrystusa w Kościele $i$ w świecie, a ustalenia w nim zawarte zostały później powtórzone w tekście Ku wspólnemu rozumieniu Kościoła. Dokument ma pewien układ dedukcyjny, rozpoczynając od bardziej ogólnych zagadnień i przechodząc do zagadnień szczegółowych. Eucharystii poświęcony został czwarty rozdział. Autorzy rozpoczynają go zaakcentowaniem biblijnego fundamentu nauczania o Wieczerzy Pańskiej, wyrażając przekonanie, że właściwe ugruntowanie skrypturystyczne, uwzględniające ekumeniczną refleksję nad Pismem Świętym, pozwoli na złagodzenie starych sporów konfesyjnych dotyczących kwestii ustanowienia Eucharystii ${ }^{41}$. Według autorów, właściwe odniesienie biblijne podkreśla wspólnotowy, w znaczeniu zarówno horyzontalnym, jak i wertykalnym, charakter celebracji Wieczerzy Pańskiej, a także ciągłość Starego i Nowego Przymierza wraz z ich odniesieniem do współczesnego świata. Stwierdzają, że w słowach ustanowienia nacisk położony jest nie tyle na kwestię, jak Chrystus jest obecny podczas Eucharystii, ale że jest On obecny osobiście ${ }^{42}$. Jednocześnie nakaz Chrystusa: „To czyńcie na moją pamiątkę” oznacza, jak stwierdzają uczestnicy dialogu, coś więcej niż tylko jakiś psychiczny akt wspomnienia ${ }^{43}$.

W drugim punkcie rozdziału, zatytułowanym Paschalna tajemnica Chrystusa i Eucharystii, dokument koncentruje się na rozumieniu zastępczego działania Chrystusa i wynikającej stąd Jego funkcji zbawczej. Autorzy przypominają, że zbawienie człowieka ma swój fundament w osobie Chrystusa i Jego dziełach. Te zaś, dokonane przez Niego w dzielonej z człowiekiem przestrzeni i czasie, są „doświadczane, wyznawane i obrazowane przez wspólnotę chrześcijańską w jej celebracji Wieczerzy z Nim"44. To stwierdzenie przywołuje wymiar pneumatologiczny; wspólnota chrześcijańska podtrzymywana jest mocą Ducha Świętego. Dalej autorzy skupiają się na podkreśleniu jedyności pośrednictwa Chrystusa. Wreszcie zaznaczają, jakby podsumowując dotychczasowy tok wypowiedzi i wprowadzając do kolejnego zagadnienia, że w Eucharystii obecny jest Chrystus, który „samego siebie wydał za nas w ofierze w dani i na wdzięczną won-

\footnotetext{
${ }^{40}$ Odnośnie do nauczania Jana Kalwina na temat Eucharystii zob. P. JAsKóŁA, Nauka Jana Kalwina o Wieczerzy Pańskiej, RTK 44 (1997) 7, 87-102.

${ }^{41}$ The Presence of Christ in Church and World, w: Growth in Agreement I, 434-463 (nr 67).

${ }^{42}$ Tamże, $\mathrm{nr} 70$.

43 Tamże.

${ }^{44}$ Tamże, nr 79.
} 
ność Bogu (Ef 5,2)”, a Kościół, „uświęcony przez Ducha Świętego (...), przez, z, i w Bożym Synu Jezusie Chrystusie, ofiaruje siebie samego Ojcu" ${ }^{45}$.

Kolejny, kluczowy jakby punkt rozdziału poświęcony jest najważniejszemu czynnikowi kontrowersji, a więc rozumieniu realnej obecności Chrystusa podczas Eucharystii, przy czym autorzy określają to zagadnienie jako centralne dla wspólnego wyznania chrześcijańskiego. Fragment ten wyraźnie wskazuje na ekumeniczną wolę poszukiwania teologicznego porozumienia. W pierwszym i drugim akapicie autorzy akcentują sakramentalny i osobowy charakter obecności Chrystusa w Eucharystii oraz funkcję Ducha Świętego w urzeczywistnianiu tej obecności we wspólnocie Kościoła. Obrazowo dodają, że Chrystus jest obecny w ,pełnej rzeczywistości Jego boskości i człowieczeństwa”.

Trzeci akapit najbardziej dotyka sedna sporu, choć autorzy tekstu „schowali” jego kwestie sporne w dwóch sposobach: w odwołaniu się do pojęcia konsubstancjacji oraz w zastrzeżeniu, że chrystologiczne nauczanie Kalwina było inspirowane patrystyczne, teologią św. Cyryla Aleksandryjskiego oraz św. Atanazego. Odnośnie do pierwszego sposobu, uczestnicy dialogu stwierdzają, że zgodnie z teologią reformowaną ,specyficzny sposób realnej obecności Chrystusa podczas Eucharystii powinien być interpretowany jako obecność Syna, który jest jednocześnie konsubstancjalny z nami, w naszej ludzkiej i cielesnej egzystencji, będąc konsubstancjalny z Ojcem i Duchem Świętym w Trójcy Świętej" "46. Po drugie, dla Kalwina inkarnacja oznaczała, że Chrystus wchodząc w cielesność i będąc w pełni zjednoczony z ludzkością, nie zamyka się w ludzkiej naturze, ale pozostaje nieskończony w skończonym ciele. Zdaniem autorów, etykietujący tę naukę termin extra Calvinisticum błędnie odnosi tę naukę do samego Kalwina, nie biorąc pod uwagę jej zakorzenienia w chrystologii Cyryla Aleksandryjskiego ${ }^{47}$.

W kolejnych punktach dokument łączy ze sobą dwie istotne wzmianki. Po pierwsze, zauważa, że celebracja Eucharystii ma swoje głęboko egzystencjalne znaczenie, jako że przypomina człowiekowi o jego wejściu w „nowe stworzenie”. Po drugie, w Eucharystii zakorzeniona jest współpraca z Chrystusem w misji wobec świata, choć, jak zaznacza dokument, misja ta jest realizowana odmiennie: Chrystus jest Pośrednikiem i Odkupicielem, a wspólnota Kościoła pełni posługę pojednania $^{48}$. To eklezjologiczne odniesienie otwiera zespół krótkich akapitów dotyczących relacji Kościoła i Eucharystii. W pierwszym podkreśla się eklezjotwórczą i wspólnototwórczą funkcję Eucharystii. Kolejny punkt jest niejako rozszerzeniem uprzedniego, akcentując fakt, że Eucharystia stanowi dla wspólnoty Kościoła

\footnotetext{
45 The Presence of Christ in Church and World, $\mathrm{nr} 81$.

46 Tamże, nr 84.

${ }^{47}$ O.D. Crisp, Divinity and Humanity. Incarnation Reconsidered, Cambridge 2007, 142.

48 The Presence of Christ in Church and World, nr 86.
} 
wzór i wezwanie dla ciągłej odnowy, w której szczególny wymiar ma dążenie do jedności oraz inspirowanie do wiarygodnego wypełniania misji wobec świata. Następny omówiony aspekt dotyczy konieczności odkrywania i reinterpretowania tych formuł dogmatycznych, które tworzone były w kontekście polemik, a które stają się obecnie źródłem nieporozumień, zwłaszcza w perspektywie ekumenicznej. Wreszcie, ostatni punkt odnosi się do porządku kościelnego, zwracając uwagę, że ustrój Kościoła nie może zaciemniać prawdziwego oblicza Kościoła, a prawo kościelne musi strzec się przed absolutyzacją samego siebie; powinno natomiast odzwierciedlać Chrystusowe prawo miłości i wolności chrześcijańskiej9

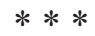

Dialogi: katolicko-luterański i katolicko-reformowany na temat chrztu i Eucharystii odzwierciedlają kondycję współczesnego ekumenizmu doktrynalnego. Warto zauważyć, że najważniejsze uzgodnienia miały miejsce w pierwszej fazie dialogu, dokumenty kolejnych w zasadzie powtarzały kluczowe treści poprzednich. W przypadkach obu dialogów wyraźnie dostrzegalne są również różne poziomy zbieżności, wynikające z historii uwarunkowań teologicznych. Ponadto, o ile sakrament chrztu nie stanowi trudności ekumenicznej, o tyle Eucharystia jest przedmiotem kontrowersji. Sformułowania tworzące treść dialogu pozwalają jednak mieć nadzieję na dalsze zbieganie się poszczególnych systemów teologicznych. Ich analiza prowadzi jednak do wniosku, że podstawowy obszar niezgodności łączy się tu z zagadnieniami posługiwania duchownego. Pomimo trudności, chrześcijanie zaangażowani w ruch ekumeniczny czekają na dalsze prace komisji dialogów. To właśnie bowiem podczas spotkań ekumenicznych, na których celebrowana jest Eucharystia, najbardziej odczuwa się podział chrześcijan.

\section{Bibliografia}

Burgess J., Gross J. (red.), Building Unity: Ecumenical Dialogues with Roman Catholic Participation in Unites States (Ecumenical Documents IV), New York: Paulist Press 1989.

CRISP O.D., Divinity and Humanity. Incarnation Reconsidered, Cambridge 2007. From Conflict to Communion. Lutheran-Catholic Common Commemoration of the Reformation in 2017, Leipzig: Evangelische Verlagsanstalt 2013.

Grane L., Wyznanie Augsburskie. Wprowadzenie w podstawowe myśli Reformacji luterańskiej, tłum. K. Lazar, J.T. Maciuszko, Bielsko-Biała 2002.

\footnotetext{
49 Tamże, nr 90.
} 
Gros J., Meyer H., Rusch W. (red.), Growth in Agreement II: Reports and Agreed Statements of Ecumenical Conversations on a World Level 1982-1998, Geneva: WCC Publications/Grand Rapids: William B. Eerdmans 2000.

JaskóŁa P., Nauka Jana Kalwina o Wieczerzy Pańskiej, „Roczniki Teologiczne” 44 (1997) 7, s. 87-102.

KANTYKa P., Dialog ekumeniczny katolicko-protestancki-założenia, zakres, rezultaty, w: M. SkŁaDANowski, T. SYcZewsKi (red.), Ekumenizm w posoborowym pótwieczu. Sukcesy i trudności katolickiego zaangażowania na rzecz jedności chrześcijan (Teologia w Dialogu 14), Lublin 2013, s. 29-50.

KARSKI K., Osiagnięcia dialogu luterańsko-reformowanego, w: J. BUDNIAK, P. JASKÓŁA, R. PorAda (red.), W nurcie myśli Jana Kalwina (Ekumenizm i Integracja 22), Opole 2009, s. 49-61.

Косн к., The Development and Challenges of Ecumenism Today, http://www. katolsk.no/tro/tema/ekumenikk/artikler/developments-and-challenges-in-ecumenism-today (10.06.2016).

KopIec P., Konsumpcjonizm. Perspektywa protestanckiej wizji człowieka i społeczeństwa, Lublin: Wydawnictwo KUL 2016.

Luter M., Mały Katechizm, w: Księgi Wyznaniowe Kościoła Luterańskiego, Bielsko-Biała: Augustana: 1999.

Meyer H., Visher L. (red.), Growth in Agreement I: Reports and Agreed Statements of Ecumenical Conversations on a World Level, 1972-1982, Geneva: WCC Publications 2007.

NAPIóRKOwSKi S.C., Bóg łaskawy, Warszawa: Biblioteka Więzi 2000.

NAPIÓRKowski S.C., Topografia dialogów międzywyznaniowych, w: W. HryNIEwicz, J.S. GAJEK, S.J. Koza (red.), Ku chrześcijaństwu jutra. Wprowadzenie do ekumenizmu, Lublin: TN KUL 1996, s. 525-541.

NAPIÓRKowsKi S.C., Wierze w jeden Kościót, Tarnów 2003.

Raport luterańsko-rzymskokatolickiej komisji studiów „Ewangelia a Kościót” (1972) (Raport z Malty), w: K. Karski, S.C. NAPIÓRKowsKi (red.), Blizej wspólnoty. Katolicy i luteranie w dialogu 1965-2000, Lublin 2003, s. 39-67.

Schulz F., Die Eucharistiefeier im katholischen Weltkatechismus. Katholische lex credendi und evangelische lex orandi. Konvergenz und Divergenz, „Liturgisches Jahrbuch" 44 (1994), s. 131-145.

SkŁadanowski M., Problemy recepcji Dokumentu z Limy z perspektywy katolickiej, „Roczniki Teologii Ekumenicznej” 4 (2012), s. 141-162.

The Apostolicity of the Church. Study Document of the Lutheran-Roman Catholic Commission on Unity, Minneapolis: Lutheran University Press 2006.

The Church as Community of Common Witness to the Kingdom of God, „Reformed World" 56 (2007) 2-3, s. 105-207. 